\title{
Cutaneous ectopic schistosomiasis: diagnostic challenge ${ }^{*}$
}

\author{
Cláudia Renata Castro do Rêgo Barros ${ }^{1}$ \\ Josemir Belo dos Santos ${ }^{1}$ \\ Jessica Guido de Araújo ${ }^{1}$
}

\author{
Daniela Cristina Caetano Maia ${ }^{1}$ \\ Camila Carolina Queiroz Medeiros ${ }^{2}$
}

DOI: http:/ / dx.doi.org/10.1590/abd1806-4841.20164647

\begin{abstract}
Cutaneous schistosomiasis is a rare clinical manifestation of schistosomiasis, an infectious and parasitic disease, caused in Brazil by the trematode Schistosoma mansoni. The lesions are due to the deposition of eggs or, rarely, adult worms, usually involving the genital and groin areas. Extra-genital lesions occur mainly on the torso as papules of zosteriform appearance. The case of a patient with ectopic cutaneous schistosomiasis is reported in this article, due to the rarity of its occurrence and its difficult clinical diagnosis.
\end{abstract}

Keywords: Schistosoma; Schistosomiasis mansoni; Skin and connective tissue diseases

A 27-year-old female patient from Quipapá/PE reported the onset of pruritic lesions on the abdomen 15 days ago. The physical examination revealed firm yellowish papules, with an erythematous-brownish base, measuring from 0.5 to $2 \mathrm{~cm}$, in groups and an ascending pattern, on the left hemiabdomen (Figure 1). She had used topical corticoid previousy, without improvement. The laboratory exams showed no alterations and the search for accarus had negative results. She mentioned frequent bathing in the river. The histopatological exam revealed granulomatous dermatitis involving parasite eggs with characteristic lateral spikes (Figures 2 and 3). Treated with Praziquantel $40 \mathrm{mg} / \mathrm{kg}$ she soon presented progressive clínical improvement (Figure 4).

Cutaneous schistosomiasis is usually aymptomatic and frequently occurs in white young women. ${ }^{1}$

The lesions are formed when eggs or worms migrate, by means of a still unknown mechanism, causing the onset of granulomas on the skin and mucosae. They are usually found in the genital and groin areas and more rarely in the extragenital region (mainly

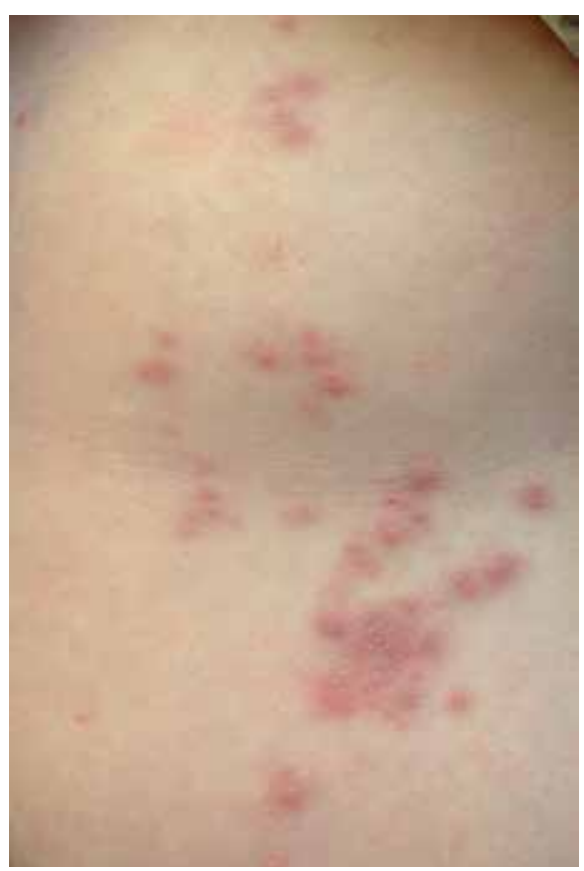

FIGURE 1:

Multiple papules of yellowish color with an erytematous-brownish base, firm, varying between 0.5 and $2 \mathrm{~cm}$ in diameter, in groups and an ascending pattern, restricted to the left hemiabdomen 


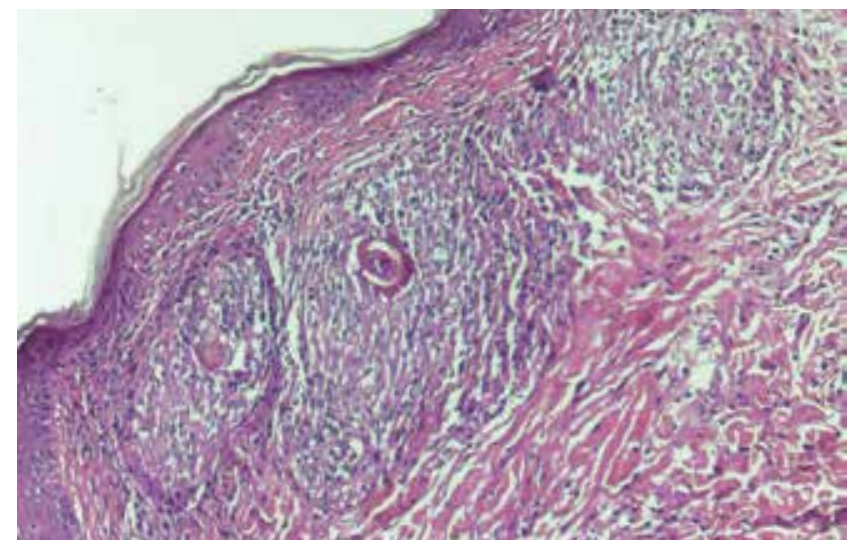

FIGURE 2: Histopathological exam, in hematoxilin-eosin, revealing multiple granulomas of foreign body (composed predominantly of lymphocytes and histiocytes), with granulomatous dermatitis involving the parasite eggs

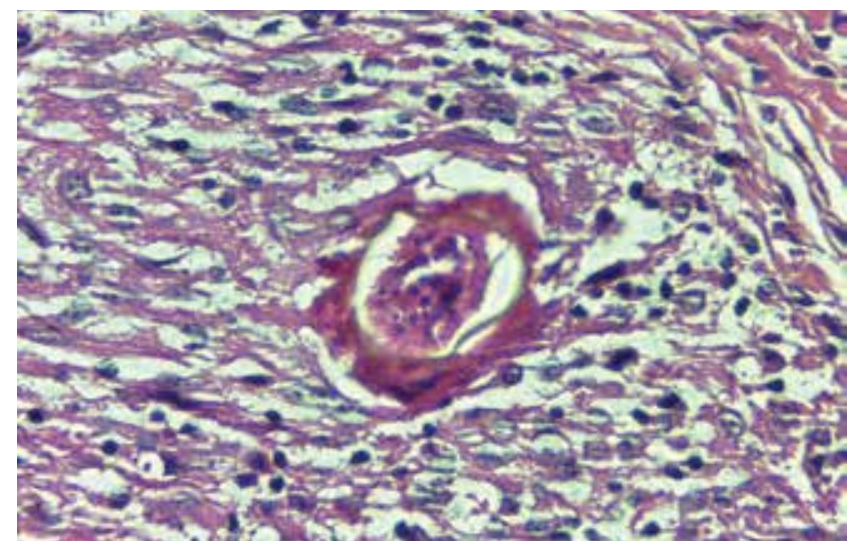

Figure 3: Detail of the parasite egg shows the characteristic prominent lateral spike

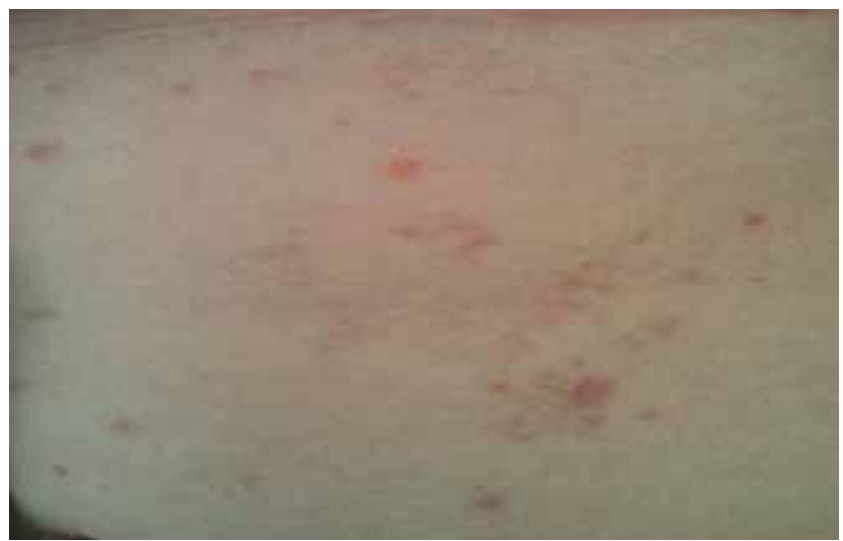

Figure 4: Almost complete regression 2 weeks after the end of the treatment with praziquantel

thorax and abdomen) ${ }^{1-3}$ Recent skin lesions present as yellowish and firm papules, in a zosteriform distribution. Old lesions may be nodular, granulomatous or vegetating lesions. ${ }^{3,5}$

The clinical diagnosis requires a high degree of suspicion and is made during the course of disease, with characteristic lesions, compatible epidemiology and histopathological exam providing identification of Schistosoma mansoni eggs. ${ }^{2}$ In recent phases the eggs are easily detected, but in old lesions necrosis and granulomatous infitrate predominate. ${ }^{4,5}$ The eggs are found in dermis and present the characteristic lateral spike. The treatment of choice is praziquantel $(40 \mathrm{mg} /$ $\mathrm{kg}$ ), with high rates of cure that vary from $60-90 \%$ (endemic areas) to $100 \%$ (non-endemic areas).

In the case reported, the clinical, epidemiological and histopathological conditions confirm the diagnosis of cutaneous ectopic schistosomiasis.

\section{REFERENCES}

1. Tranquillini G, Hostalácio IFF, Villa RT, Silva LAG, Leitão R, Bedin V. Esquistossomose cutânea ectópica: relato de caso. Med Cutan Iber Lat Am. 2011;39:268-71.

2. Costa IMC, Moreira RR, Moraes MAP. Esquistossomose mansônica cutânea ectópica. An Bras Dermatol. 1989;64:183-4.

3. Atanda AT, Mohammad MS, Atallah L. Cutaneous schistosomiasis: Case report and literature review. Ann Nigerian Med. 2012;6:98-100.

4. Reed LD, Theis JH. Cutaneous schistosomiasis: report of a case and review of the literature. J Am Acad Dermatol. 2000;42:678-80.

5. Andrade Filho J de S, Lopes MS, Corgozinho Filho AA, Pena GP. Ectopic Cutaneous Schistosomiasis: Report of two Cases and a Review of the Literature. Rev Inst Med Trop Sao Paulo. 1998;40:253-7.

\author{
MAILING ADDRESS: \\ Cláudia Renata Castro do Rêgo Barros \\ Av. Prof. Moraes Rego, 1235 \\ Cidade Universitária \\ 50670-901 Recife - PE. \\ E-mail:claudinha_rbarros@hotmail.com
}

How to cite this article: How to cite this article: Barros CRCR, Maia DCC, Santos JB, Medeiros CCQ, Araújo JG. Cutaneous ectopic schistosomiasis: diagnostic challenge. An Bras Dermatol. 2016;91(1):109-10. 